Journal of Southeast Asian

2010

\title{
Book Review: Reflections of a Khmer Soul by Navy Phim
}

Silvy Un

University of Minnesota, slafayette@brookcntr.k12.mn.us

Follow this and additional works at: https://docs.lib.purdue.edu/jsaaea

Part of the Asian American Studies Commons

\section{Recommended Citation}

Un, Silvy (2010) "Book Review: Reflections of a Khmer Soul by Navy Phim," Journal of Southeast Asian American Education and Advancement. Vol. 5 : Iss. 1, Article 11.

DOI: $10.7771 / 2153-8999.1012$

Available at: https://docs.lib.purdue.edu/jsaaea/vol5/iss1/11

This document has been made available through Purdue e-Pubs, a service of the Purdue University Libraries. Please contact epubs@purdue.edu for additional information.

This is an Open Access journal. This means that it uses a funding model that does not charge readers or their institutions for access. Readers may freely read, download, copy, distribute, print, search, or link to the full texts of articles. This journal is covered under the CC BY-NC-ND license. 


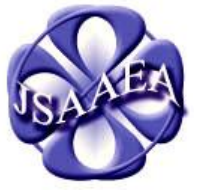

Volume 5 (2010)
Journal of Southeast Asian American

Education \& Advancement

WWW.JSAAEA.org
A peer-reviewed

scholarly journal

published by the

National Association

for the Education \&

Advancement of

Cambodian, Laotian,

and Vietnamese

Americans (NAFEA)

\title{
Book Review
}

\section{Phim, N. (2007). Reflections of a Khmer soul. Tucson, AZ: Wheatmark. 149 pp. \$14.95 (paperback). ISBN: 9781587368615.}

\author{
Reviewed by \\ Silvy Un \\ University of Minnesota
}

Reflections of a Khmer Soul, by Navy Phim, is a narrative by a Cambodian American female who attempts to make sense of the war in Cambodia by reflecting on her life experiences. Though time and distance have taken Phim away from Cambodia's war, experiences with family, identity, and her travels abroad provide lenses through which she returns to make sense of what happened. As I read her narrative with the lens of a 1.5-generation Cambodian American and former middle school teacher, who has taught many Cambodian students sharing

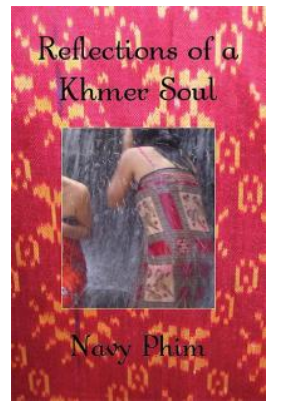
in this experience, I find that Phim's book has strengths and weaknesses. Strengths include Phim's ability to convey the reality that all Cambodians experienced the war differently. Her writing also illustrates resilience among refugees. Though her narrative is personal, Phim's stories also unify readers along lines of nationality, ethnicity, and life experience. Parts of her story have important implications for educators working with students from immigrant families as well. On the other hand, I believe that her book demonstrates two weaknesses: structure and bias. Phim's thoughts are organized in "parts" based on themes that are interesting to read, but not clearly defined. Though the organization of this book may delight readers who enjoy mosaic journeys, an audience drawn to linearity in storytelling may find this book "difficult" to read. Towards the end of her narrative, she also hurls remarks about "rich" and "poor" Cambodian refugees that some readers may find to be disingenuous and dangerous.

Parts one and two of Phim's book discusses her family's journey from Cambodia to the United States. Born on April 9, 1975, her physical journey begins as the war in Cambodia shifts from a boil to an explosion that later transforms her native country into the Killing Fields, led by the Khmer Rouge. One of the Khmer Rouge's goals was to exterminate educated Cambodians and urban elites. As farmers, Phim's parents' status protected them from the Khmer Rouge. Their background allowed her family the option to emigrate from Cambodia, whereas other Cambodians whose families were targeted by the Khmer Rouge viewed emigration as a necessity for survival. In fact, the only reason why Phim's parents traveled to Thailand in the first place is

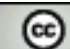

SOMERIGHISRESERVED Readers are free to copy, display, and distribute this article, as long as the work is attributed to the author(s) and the Journal of Southeast Asian American Education \& Advancement, it is distributed for noncommercial purposes only, and no alteration or transformation is made in the work. More details of this Creative Commons license are available at http://creativecommons.org/licenses/by-nc-nd/3.0/. All other uses must be approved by the author(s) or JSAAEA. 
to help her paternal grandparents smuggle goods into Cambodia for re-sale. Instead of returning to Cambodia, her parents decided to enter the Thai refugee camp with other Cambodian refugees. Of this experience, Phim writes, "my mother portrayed the road to America as packed with accidental good fortune and a dash of good karma" (p. 12). I wonder how many Cambodian refugees were fortunate enough to describe their experience in this way? Based on this unique perspective, I believe that Phim's story is important for understanding that all Cambodians did not experience the war equally.

Phim's reflections on life in the refugee camp are also important, because she contributes a different image of refugees by not focusing on destitute memories. Instead, her narrative reflects the innocence and optimism of a child who still found humor, comfort, and love among those around her during this terrible time. Phim also writes about a makeshift economy that refugees built discretely, despite threats from Thai soldiers patrolling the camp. Images illustrated through Phim's writing portray Cambodian refugees as strong, clever, brave, and agentive. This perspective is often missing in literature about refugees.

Part two highlights Phim's family's story about resettlement in Long Beach, California. Although she focuses exclusively on her family's experience, Phim intelligently exhibits topics relatable to many Cambodian Americans and other U.S. immigrants. Connections are merged between readers as she writes about her mother's garden that grows vegetables common to Khmer dishes, debates over skin color and beauty among relatives, and traditional medicinal practices such as coining or "kaus kjol." Written as her own story, these reflections are really about acculturation in the U.S. Read in this way, other immigrants in the U.S. may find their own experiences reflected in Phim's narrative.

Followed by stories of Phim's family's journey to the U.S. are her reflections on Cambodia's culture and history (part three) and an analysis of how her hyphenated Cambodian American identity fit into her definition of what it means to be Khmer after the war (part four). In this part of her book, she recites Cambodian mythology to emphasize the strength of Cambodia's history. She also uses metaphors of multicolored fabrics in traditional Khmer clothing to describe the phenotypic diversity of Cambodian people. This metaphor powerfully expresses how Cambodians look different individually, but as a group we re-create the fabric of Khmer history and culture. Her writing also shows that it is our different features that keep us connected to other people in the world.

By reflecting on her own identity as a hyphenated Cambodian American, Phim suggests that the Cambodian diaspora now adds another dimension to what it means to be Khmer. Her narrative reveals moments when she feels caught along this border. Despite her ambivalence at times, Phim's physical identification as an ethnic outsider in the U.S. often forced her to act as a representative for all Cambodian immigrants. Her story reveals that these feelings were heightened when inquisitive non-Cambodians, like her schoolteachers, asked questions related to the war. As a child educated in the U.S. public school system, how could she know such answers if this subject is rarely taught? Consequently, Phim recalls feelings of embarrassment for being asked these questions, and shame when she did not know the answer.

This story has many important implications for educators working with students from immigrant backgrounds. First, Phim's narrative highlights the importance of creating opportunities for Cambodian American students to learn about their family's history in school, because it helps youth understand themselves as well. Her story also validates the need for educators to be conscious of teaching students about their family's history in ways that do not marginalize them in class. By including content that represents the histories and interests of 
students in the classroom, some scholars argue that students who are personally connected to curriculum will be more motivated to learn and feel like leaders in school (Ladson-Billings, 1992a, 1992b, 1995, 1997). Since the high school graduation rate of Cambodian American students lingers below 50\% (Southeast Asia Resource Action Center [SEARAC], 2004), I believe that Phim's narrative is timely and critical.

As she grew older, Phim recalls searching through books and biographies written by Cambodian authors to piece together an explanation for why the war in Cambodia occurred. Here she reminds readers that she is not alone on this mission. Phim writes, "there have been many ill-fated attempts to create, inspire, and unite our shattered identities. Internet communities, forum discussions, literary journals, and other types of websites have sprung out of our desire to heal and educate ourselves and others" (p. 67). Phim's comment is significant for researchers who express concern over Cambodian Americans' forced integration into pan-ethnic categories in many U.S. institutions (Kiang, 2006; Lee, 2006). As an extension of Kiang (2006) and Lee's (2006) research, I believe that Phim's point accurately conveys the fact that many Cambodian Americans are looking to learn more about their own unique ethnic identity. I also agree with Phim's sentiment that learning is largely based on "whether or not we care to know and make the time to educate ourselves and begin the journey toward healing and understanding" (p. 69). Adding to this comment, I argue that the work to learn, discuss, analyze, and heal should also be done collaboratively with educators and community members.

When she visits Cambodia as an adult, she witnesses how wealthy Cambodians treated their servants with cruelty. Though angry at the war in Cambodia, these behaviors among the wealthy towards their workers compel Phim to try and understand why some Cambodians may have been angry enough to side with the Khmer Rouge. Stuck between hating the Khmer Rouge and empathizing with the poor, Phim turns to religion and questions how a higher being could ever allow people to treat each other this way. While Phim questions her faith, she ties these thoughts to other moments in history, such as the Holocaust. As Phim shares her struggle to hate and empathize with victimizers and victims simultaneously, her writing exudes the strength of unity. Moreover, Phim's narrative reveals that the struggle to understand and heal is both historical and global.

The last section of her book, part seven, contains Phim's final reflections on the war in Cambodia, identity, family, culture, and humanity. With the exception of her discussion about rich and poor Cambodian immigrants in the U.S., this section is mainly a continuation of thoughts presented earlier in her book. Thus, this part is aptly titled "Final Thoughts."

Phim's elaboration of her biases about rich and poor Cambodian refugees and immigrants, subtitled "An Undisputed Truth," is a new addition to her reflections. I believe that it is also the biggest weakness in her book. In "An Undisputed Truth," Phim juxtaposes rich and poor Cambodian immigrants. She writes, "in my mind's eye, I can divide the Cambodian community of Long Beach into two types based on their previous status in Cambodia, the rich city people and the poor farmers. The former has little problem making it in America" (p. 132). In response to this allegation, I pose the question: How many rich Cambodian refugees actually came to the U.S.?

As a child of educated parents who were once fairly wealthy before the war, I take offense to this statement. Like many refugees in the U.S., my family found that employers were less than impressed by my parents' former wealth and education from Cambodia. Similar to many Cambodian refugees' stories documented in research (Ong, 2003), my family dealt with 
poverty, discouragement from schools, racism from neighbors, and exploitation from employers. How are we more privileged than Phim's family?

This part of Phim's book is also deceptive because the author is privileged in ways that she does not acknowledge. To the neglect of her own elite status, she writes, "I am familiar with the farmers of Cambodia, which include my parents . . our parents were sweatshop workers ... or at the factories twelve hours a day" (pp. 132-133). Despite this claim, various aspects of her identity and experience set Phim apart from Cambodian immigrants who are less privileged. For example, Phim writes that "both of my parents are literate" (p. 130), but does not explain that of the $69 \%$ of Cambodian Americans who were foreign born, 26.2\% of that population (age 25 and over) had no formal schooling (Ngo, 2006). This is significant because the fact that Phim and I are both college educated is related to our parents' literacy, which helped us navigate the U.S. school system more successfully than students whose parents are not literate (Schmid, 2001). Phim also shares a story about her college orientation, but ignores the fact that she is a member of only $9.1 \%$ of Cambodians (age 25 and older) who actually holds a bachelor's degree (SEARAC, 2004). Though Phim's statement attempts to paint her narrative as being uniquely different based on her family's socioeconomic background, I find her comment to be clumsy and dangerous. Not only is she lacking transparency, but her comment undermines data pointing to the reality of educational and economic disparities among many Cambodian Americans in the U.S. (Ong, 2003; Reyes, 2006; SEARAC, 2004), which are often masked by their placement into pan-Asian categories (Kiang, 2006; Lee, 2006). These realities exist regardless of how wealthy some Cambodians once were prior to the war. Readers, especially Cambodian Americans whose experiences are similar to mine, should take caution when approaching this part of her story.

Although there are some weaknesses in Phim's Reflections of a Khmer Soul, I believe that the strengths in her book make it a valuable read for multiple audiences. As a middle school math teacher who was often asked by my Cambodian students about what happened in Cambodia, I believe that Phim's book is extremely important for Cambodian American youth and educators. Above all, Reflections of a Khmer Soul represents Phim's journey to understand her identity and make sense of Cambodia's war and its aftermath. Phim recognizes that many refugees are learning, reflecting, and healing in different ways. For those who are not engaged in this work, her narrative urges them to start.

\section{References}

Kiang, P. N. (2006). Policy challenges for Asian American and Pacific Islanders in education. Race Ethnicity and Education, 9(1), 103-115.

Ladson-Billings, G. (1992a). Liberatory consequences of literacy: A case of culturally relevant instruction for African American students. The Journal of Negro Education, 61(3), 378391.

Ladson-Billings, G. (1992b). Reading between the lines and beyond the pages: A culturally relevant approach to literacy teaching. Theory into Practice, 31(4), 312-320.

Ladson-Billings, G. (1995). Toward a theory of culturally relevant pedagogy. American Educational Research Journal, 32(3), 465-491.

Ladson-Billings, G. (1997). It doesn't add up: African American students' mathematics achievement. Journal for Research in Mathematics Education, 28(6), 697-708.

Lee, S. J. (2006). Additional complexities: Social class, ethnicity, generation, and gender in Asian American student experiences, Race Ethnicity and Education, 9(1), 17-28. 
Ngo, B. (2006). Learning from the margins: The education of Southeast and South Asian Americans in context. Race Ethnicity and Education, 9(1), 51-65.

Ong, A. (2003). Buddha is hiding. Berkley, CA: University of California Press.

Phim, N. (2007). Reflections of a Khmer soul. Tucson, AZ: Wheatmark.

Reyes, A. (2006). Language, identity, and stereotype among Southeast Asian American youth: The other Asian. Mahwah, NJ: Lawrence Erlbaum Associates.

Schmid, C. (2001). Educational achievement, language minority students and the new second generation. Sociology of Education, 74, 71-87.

Southeast Asia Resource Action Center. Southeast Asian American statistical file [Data File]. Retrieved from http://www.searac.org/seastatprofilemay04.pdf

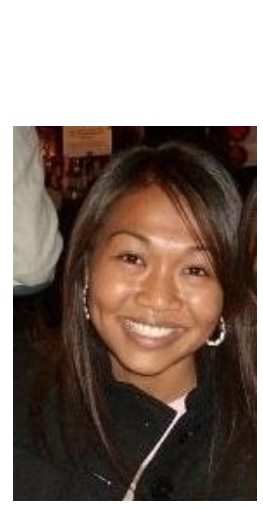

\section{About the Reviewer}

Born in the Kao-I-Dang refugee camp along the Thai/Cambodian border, Silvy now lives in Minnesota as a 1.5 generation Cambodian American. She is currently a third year PhD student at the University of Minnesota - Twin Cities in the College of Education and Human Development. After completing her undergraduate degree at the University of Notre Dame, she earned her master's degree in Elementary Education at Boston College's Lynch School of Education, where she was a Donovan Urban Teaching Scholar and Jay Sharp Scholar. Her research interests include immigrant education, youth activism, culturally relevant pedagogy, critical pedagogy, and postcolonial and feminist theories. 


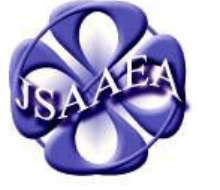

Volume 5 (2010)

\section{Journal of Southeast Asian American Education \& Advancement} WWW.JSAAEA.org
A peer-reviewed scholarly journal published by the National Association for the Education \& Advancement of Cambodian, Laotian, and Vietnamese Americans (NAFEA)

Editor

Dr. Wayne E. Wright

University of Texas, San Antonio

Associate Editors

Dr. Chhany Sak-Humphry

University of Hawaii

Dr. KimOanh Nguyen-Lam

California State University, Long Beach

Book Review Editor

Dr. Vichet Chhuon

University of Minnesota

Creative Works Editor

Bryan Thao Worra

Lao Assistance Center

\section{Special Advisor}

Gregory Green

Curator, Echols Collection on Southeast Asia, Cornell University Library

\section{Editorial Assistant}

Kathleen Langham

University of Texas, San Antonio

Comments and questions for the editorial staff may be directed to jsaaea@ lists.sis.utsa.edu

\section{Editorial Review Board}

\author{
Dr. Carl L. Bankston III \\ Tulane University \\ Dr. Phala Chea \\ Lowell Public Schools \\ Dr. Loan Dao \\ Cancer Prevention Institute of California \\ Dr. Sophal Ear \\ U.S. Naval Postgraduate School \\ Dr. Samlong Inthaly \\ Minneapolis Public Schools \\ Dr. Kevin K. Kumashiro \\ University of Illinois, Chicago
}

\author{
Dr. Pollie Bith-Melander \\ Asian and Pacific Islander Wellness Center \\ Dr. George Chigas \\ University of Massachusetts, Lowell \\ Dr. Changming Duan \\ University of Missouri, Kansas City \\ Dr. Nancy H. Hornberger \\ University of Pennsylvania \\ Dr. Peter Nien-Chu Kiang \\ University of Massachusetts, Boston \\ Dr. Stacey Lee \\ University of Wisconsin, Madison
}




\author{
Dr. David Chanpannha Ley \\ Montgomery County Public Schools \\ Dr. Bic Ngo \\ University of Minnesota \\ Dr. Leakhena Nou \\ California State University, Long Beach \\ Dr. Mark Pfeifer \\ Texas A\&M University, Corpus Christi \\ Dr. Bounlieng Phommasouvanh \\ Minnesota Department of Education \\ Dr. Kalyani Rai \\ University of Wisconsin, Milwaukee \\ Dr. Nancy J. Smith-Hefner \\ Boston University \\ Dr. Myluong Tran \\ San Diego State University \\ Dr. Linda Trinh Vo \\ University of California, Irvine \\ Dr. Zha Blong Xiong \\ University of Minnesota
}

Dr. Sue Needham

California State University, Dominguez Hills

Dr. Max Niedzwiecki

Daylight Consulting Group

Dr. Clara Park

California State University, Northridge

Dr. Loan T. Phan

University of New Hampshire

Dr. Karen Quintiliani

California State University, Long Beach

Dr. Fay Shin

California State University, Long Beach

Dr. Yer J. Thao

Portland State University

Dr. Khatharya Um

University of California, Berkeley

Dr. Terrence G. Wiley

Arizona State University

Dr. Kou Yang

California State University, Stanislaus

\section{Doctoral Student Editorial Review Board}

\author{
Keo Chea-Young \\ University of Pennsylvania \\ Peter Tan Keo \\ Columbia University \\ Ha Lam \\ Arizona State University \\ Monirith Ly \\ Texas State University \\ Vanna Som \\ Harvard University \\ Layheng Ting \\ State University of New York, Albany \\ Tinou Tran \\ University of Houston, Texas
}

\author{
Annie BichLoan Duong \\ San Joaquin County Office of Education \\ Polinda Keo
University at Albany \\ Ravy Lao \\ University of California, Santa Barbara
}

\section{Giang Pham \\ University of Minnesota}

Rassamichanh Souryasack

University of California, Santa Barbara

Loan Tran

University of California, Riverside

Phitsamay Sychitkokhong Uy

Harvard University

Yang Sao Xiong

University of California, Los Angeles 